European journal of American studies

\title{
The Many Meanings of D-Day
}

Kate Delaney

\section{(2) OpenEdition}

Journals

Electronic version

URL: https://journals.openedition.org/ejas/9544

DOI: $10.4000 /$ ejas.9544

ISSN: 1991-9336

Publisher

European Association for American Studies

\section{Electronic reference}

Kate Delaney, "The Many Meanings of D-Day", European journal of American studies [Online], 7-2 | 2012, document 13, Online since 29 March 2012, connection on 08 July 2021. URL: http://

journals.openedition.org/ejas/9544 ; DOI: https://doi.org/10.4000/ejas.9544

This text was automatically generated on 8 July 2021 .

Creative Commons License 


\title{
The Many Meanings of D-Day
}

\author{
Kate Delaney
}

1 For Americans, June 6, 1944 "D-Day" has come to symbolize World War II, with commemorations at home and abroad. How did this date come to assume such significance and how have the commemorations changed over the 65 years since the Normandy landings? How does D-Day function in U.S. cultural memory and in domestic politics and foreign policy? This paper will look at some of the major trends in D-Day remembrances, particularly in international commemorations and D-Day's meaning in U.S. and Allied foreign policy. Although war commemorations are ostensibly directed at reflecting on the hallowed past, the D-Day observances, particularly since the 1980s, have also marked new beginnings in both domestic and foreign policy.

2 As the invasion was taking place in June 1944, there was, of course, a great deal of coverage in the U.S. media. The events in Normandy, however, shared the June headlines with other simultaneous developments on the European front including the fall of Rome. ${ }^{1}$

\section{Early Years}

3 The very first anniversary of the D-Day landings was marked on June 6, 1945 by a holiday for the Allied forces. In his message to the troops announcing the holiday General Eisenhower stated that "formal ceremonies would be avoided." 2

By the time the invasion's fifth anniversary rolled around in 1949 the day was marked by a "colorful but modest memorial service" at the beach. The U.S. was represented at the event by the military attaché and the naval attaché of the U.S. Embassy in Paris. A French naval guard, a local bugle corps and an honor guard from an American Legion Post in Paris all took part. A pair of young girls from the surrounding villages placed wreaths on the beach, and a U.S. Air Force Flying Fortresses passed over, firing rockets and dropping flowers. ${ }^{3}$

5 The anniversaries of the early 1950s reflected the tenor of the times, evoking both the economic and military Cold War projects of the U.S. in Europe: the Marshall Plan and 
NATO. Barry Bingham, head of the Marshall Plan Mission in France, used the occasion of the 1950 D-Day commemoration ceremony to praise France's postwar recovery efforts. ${ }^{4}$ Held in the middle of the Korean War, the 1952 D-Day commemoration at Utah Beach proved an opportunity for General Matthew D. Ridgway, Supreme Commander Allied Forces in Europe and a D-Day veteran, to speak of U.S. purpose in the Cold War against "a new and more fearful totalitarianism." He warned the Communist powers not to "underestimate our resolve to live as free men in our own territories....We will gather the strength we have pledged to one another and set it before our people and our lands as a protective shield until reason backed by strength halts further aggression...." Referring to both his status as a D-Day participant and his current role as military commander of NATO, Ridgway pledged: "The last time I came here, I came as one of thousands to wage war. This time I come to wage peace." ${ }^{5}$

The tenth anniversary of the D-Day landings found President Dwight Eisenhower, who as Commander of the Supreme Headquarters Allied Expeditionary Force (SHAEF) had led the Normandy invasion, strolling through a wheat field in Gettysburg, Pennsylvania. ${ }^{6}$ Eisenhower sent a statement to be read at the Utah Beach commemoration ceremony by the U.S. Ambassador to the United Nations Henry Cabot Lodge, Jr. who was the President's personal representative at the anniversary events. In contrast to the bellicose remarks of General Ridgway a few years earlier, Eisenhower in 1954 expressed "profound regret" that all of "the members of the Grand Alliance have not maintained in time of peace the spirit of that wartime union." Eisenhower used this anniversary occasion to recall "my pleasant association with the outstanding Soviet Soldier, Marshall Zhukov, and the victorious meeting at the Elbe of the armies of the West and of the East." A decade later, in preparation for the twentieth anniversary of the D-Day landings, Eisenhower, no longer president, returned to the Normandy beaches in 1963 to film a D-Day TV special for CBS. ${ }^{8}$

7 In between the tenth and twentieth anniversaries, U.S. domestic interest in the Normandy landings had been stoked by Cornelius Ryan's 1959 best-seller The Longest Day and the 1962 Hollywood epic that Darryl F. Zanuck produced based on Ryan's book. The film was also notable for giving separate attention to the contributions of the British and Canadian forces as well as those of the French Resistance. The German actions in Normandy were depicted without demonization. Leading German actors (speaking German) gave voice to the professional military's criticism of Hitler's leadership. This empathetic portrayal was an indication perhaps of West Germany's position in the NATO alliance. Clocking in at 178 minutes and shot in black and white for a documentary feel, The Longest Day boasted a cast that was a Who's-who of British and American male stars of the era: John Wayne, Henry Fonda, Robert Mitchum, Richard Burton, Peter Lawford, Sean Connery, Richard Beymer, Red Buttons, Eddie Albert, and teen heart-throbs Fabian, Paul Anka, Tommy Sands and Sal Mineo. This display of bold-face names served to undercut the film's intended documentary effect as their presence constantly reminded the viewers that they were watching a Hollywood production. Critics pointed out that Zanuck's attention to period detail in weapons, equipment and language did not carry through to a realistic depiction of combat death and casualties-a charge that could not be laid against Steven Spielberg for Saving Private Ryan a 1998 Hollywood D-Day block-buster. ${ }^{9}$

8 In spite of this heightened public interest in D-Day, U.S. President Lyndon Johnson, absorbed in both his ambitious domestic agenda-including trying to secure passage of 
the Civil Rights Act-- and the Vietnam War, did not travel to Normandy for the twentieth anniversary. Instead he sent General Omar N. Bradley, one of the commanders of the 1944 landings. ${ }^{10}$

9 For the twenty-fifth anniversary in 1969 President Richard Nixon, focused on Vietnam, issued a boilerplate proclamation, calling the Allied landings in 1944 "'a historical landmark in the history of freedom." "11 When the time came for the thirtieth anniversary of D-Day in 1974, Nixon again was too preoccupied to travel to Normandy. Congress had already begun impeachment hearings against him on charges of obstruction of justice, abuse of power and contempt of Congress arising from the Watergate affair. Nixon would resign in August 1974, and Presidential attention for the rest of the 1970s was directed at the aftermath of Vietnam and at new crisis like those involving the U.S. economy, energy, and the seizing of the U.S. Embassy in Teheran. The moment for actively reinvigorating the memory of World War II had not yet arrived.

As the G-7 leaders ${ }^{12}$ gathered in Paris for their meetings at Versailles in early June 1982, President Ronald Reagan made D-Day the focus of his radio broadcast to U.S. audiences on June 5. He also prepared taped remarks on D-Day for broadcast on French television. ${ }^{13}$ Although the President himself did not travel to the landing sites in 1982, U.S. First Lady Nancy Reagan paid a three-hour visit to Normandy to mark the thirty-eighth anniversary of D-Day. ${ }^{14}$ Accompanied by the Defense and Army attachés of the U.S. Embassy in Paris, she laid a wreath at the memorial statue in the U.S. cemetery in Colleville-sur-Mer and made some brief remarks to a small crowd: "If my husband were here today, he would tell you how deeply he feels the responsibilities of peace and freedom. He would tell you how we can best insure that other young men on other beaches and other fields will not have to die. And I think he would tell you of his ideas for nuclear peace." ${ }^{\prime 15}$

\section{2. "Morning Again in America"}

11 Two years later on the fortieth anniversary of D-Day in June 1984 her husband President Ronald Reagan would get the chance to personally address those gathered to commemorate the Normandy invasion. But this time the crowd was no longer small. Speaking at the Ranger Monument at Pointe du Hoc at 1:20 p.m. (timed to coincide with the morning TV programs on the U.S. East Coast and designed as part of Reagan's reelection campaign) President Reagan delivered his now-famous "boys of Pointe du Hoc" address to a television audience of millions as well as to the veterans and Allied leaders gathered on the Normandy coast. In remarks carefully crafted by Peggy Noonan, Reagan first paid tribute to the Ranger veterans, recreating dramatically their heroic deeds in scaling the cliffs: "They climbed, shot back, and held their footing. Soon, one by one, the Rangers pulled themselves over the top, and in seizing the firm land at the top of these cliffs, they began to seize back the continent of Europe. Two hundred and twenty-five came here. After two days of fighting, only ninety could still bear arms." He went on to pay tribute to the Allies, mentioning by name "the Royal Winnipeg Rifles, Poland's 24th Lancers, the Royal Scots Fusiliers, the Screaming Eagles, the Yeomen of England's armored divisions, the forces of Free France, the Coast Guard's 'Matchbox Fleet' and you, the American Rangers." Not leaving out Germany and Italy, Reagan spoke of the reconciliation with former enemies "all of whom had suffered so greatly. 
The United States did its part, creating the Marshall plan to help rebuild our allies and our former enemies. The Marshall plan led to the Atlantic alliance -- a great alliance that serves to this day as our shield for freedom, for prosperity, and for peace." Toward the Russians, Reagan presented two faces. ${ }^{16}$ First, he lamented: "Some liberated countries were lost. The great sadness of this loss echoes down to our own time in the streets of Warsaw, Prague, and East Berlin. Soviet troops that came to the center of this continent did not leave when peace came. They're still there, uninvited, unwanted, unyielding, almost 40 years after the war." Then he added: "It's fitting to remember here the great losses also suffered by the Russian people during World War II: 20 million perished.... We look for some sign from the Soviet Union that they are willing to move forward, that they share our desire and love for peace, and that they will give up the ways of conquest." After his remarks he unveiled two memorial plaques honoring the Rangers. ${ }^{17}$

12 The Pointe du Hoc speech served as the opening salvo in Reagan's "morning again in America" re-election campaign. Using snippets from this speech in a popular television advertisement, the campaign transformed a look back at a forty-year-old battle into a new beginning for the nation. ${ }^{18}$

13 A few hours after the Pointe du Hoc speech Reagan gave another address on Omaha Beach, this time paying special tribute to the efforts of the French Resistance, directing his remarks at President Mitterrand, who had participated in the Resistance. "Your valiant struggle for France did so much to cripple the enemy and spur the advance of the armies of liberation. The French Forces of the Interior will forever personify courage and national spirit." Reminding Americans and Europeans of the importance of postwar efforts like NATO, he concluded: "Our alliance, forged in the crucible of war, tempered and shaped by the realities of the postwar world, has succeeded. In Europe, the threat has been contained, the peace has been kept."19

Later that same day President Reagan joined President Mitterrand and other Allied leaders (Queen Elizabeth II of the United Kingdom, Queen Beatrix of The Netherlands, King Olav V of Norway, King Baudouin I of Belgium, Grand Duke Jean of Luxembourg, and Prime Minister Pierre Elliott Trudeau of Canada) at Utah Beach. Mitterrand's remarks stressed reconciliation with Germany: "the adversaries of yesterday are reconciled and are building the Europe of freedom."' ${ }^{20}$ Chancellor Helmut Kohl had not been invited to the ceremonies, but the day's events and speeches buttressed a NATO alliance that included (West) Germany.

This emphasis on the continuing importance of the NATO alliance was far from accidental. There are been widespread protests in Europe in 1984 over the installation of U.S. Cruise and Pershing missiles in accordance with a 1979 NATO decision. The "family portrait" of the assembled Allies on Utah Beach and the tribute to their absent member Germany sent a signal to publics on both sides of the Atlantic about the continuing commitment to joint defense of "the Europe of freedom." The 1984 celebrations set a new standard for D-Day commemorations and established a pattern that would be followed (with variations) for the next twenty-five years. By looking at these variations in subsequent years we can monitor changes in transatlantic relations. 


\section{A New Europe}

16 By the time of the fiftieth anniversary of D-Day the map of Europe had shifted once again. The Warsaw Pact had dissolved; Germany had reunited; Czechoslovakia had split; the Soviet Union was no more. In June 1994 leaders of all the countries that had participated in the invasion gathered at Normandy: Australia, Belgium, Canada, France, Greece, Luxembourg, the Netherlands, New Zealand, Norway, the UK and the U.S. and this year for the first time leaders of Poland and the Czech Republic and Slovakia-a visible symbol of the changed faced of Europe since 1989 and yet another new beginning for the continent. In addition the year marked a generational shift, with the U.S. represented in Normandy by President Clinton who had been born after the end of World War II.

17 Clinton, of course, had a hard act to follow given the iconic status that Reagan's "boys of Pointe du Hoc" speech had attained over the past decade. He also had the disadvantage of never having served in the military and of having famously avoided serving in the Vietnam War. In a new wrinkle to D-Day celebrations, Clinton, along with Queen Elizabeth and other Allied leaders, sailed from Portsmouth, England to the French coast in a "massive flotilla" accompanied by Lancaster bombers to recreate and commemorate the 1944 invasion. ${ }^{21}$ In France Clinton participated in four ceremonies marking the anniversary of the landings. In his address at the American cemetery he turned his seeming disadvantage of lack of WWII experience into an advantage as he stressed the ties between generations: "WWe are the children of your sacrifice," he told the veterans of D-Day. "The flame of your youth became freedom's lamp, and we see its light reflected in your faces still, and in the faces of your children and grandchildren....We commit ourselves, as you did, to keep that lamp burning for those who will follow. You completed your mission here. But the mission of freedom goes on; the battle continues. The 'longest day' is not yet over."'22

D-Day anniversaries were not only occasions for major political gatherings and speeches, but had also become important tourist attractions and income generators for Western Europe, especially France, with Normandy hotels and guest houses fully booked for early June. In 1994 France alone hosted more than 350 events commemorating the D-Day landings. Many specialized tours were designed for veterans and their families. The QE2 even offered a cruise to Cherbourg featuring 1940s big bands, Vera Lynn and Bob Hope. ${ }^{23}$ Across the Channel, thousands of veterans and their families were also welcomed at anniversary events in England. ${ }^{24}$

Ten years later for the sixtieth anniversary of D-Day President George W. Bush faced a double challenge: how to repair the Alliance after the visible rupture over the Iraq War and how to compete with the memory of Ronald Reagan, whose exquisitely timed death on June 5, 2004 insured that the Great Communicator's 1984 D-Day speeches would be replayed prominently on June 6 , making comparisons between the two presidents unavoidable. The attack on Iraq in 2003 had become a point of contention among NATO Allies, with France and Germany refusing to support the war. French President Chirac as host of the Normandy commemorations invited German Chancellor Gerhard Schröder to the commemorations held in Caen and Arromanche, the first time a German leader had been included in the celebrations. ${ }^{25}$ Although Chirac's predecessor Mitterrand had gone out of his way to emphasize conciliation with Germany in his remarks twenty years before, on the fiftieth anniversary in 1994 Chancellor Helmut 
Kohl had not been invited to attend any Normandy events. At the time Kohl remarked, "There was 'no reason' for a chancellor of Germany 'to celebrate when others mark a battle in which tens of thousands of Germans met miserable deaths." Schröder declared that his invitation to the 2004 Normandy commemoration "meant that "Germany's long journey to the West has now been completed," ${ }^{26}$ signaling a new beginning for German identity within the community of Western nations.

The 1944 Normandy invasion had been, of course, an attack on German forces occupying France, but Schröder had been allied with Chirac in opposing the 2003 Iraq War. Prime Minister Silvio Berlusconi of Italy, who supported the Iraq War, on the other hand, was not invited to the 2004 celebrations. However, Tony Blair, Bush's close ally in the Iraq War, was there along with Queen Elizabeth. President Vladimir Putin of Russia also attended-- another first. During the Cold War the Soviet Union had not been included in the Normandy celebrations, in spite of its contributions to the Allied victory in World War II. Leaders and royalty from Australia, Belgium, Canada, the Czech Republic, Greece, Luxembourg, the Netherlands, Norway, Poland, Slovakia and New Zealand also participated in the sixtieth anniversary events.

21 President Bush addressed the gathered veterans and heads of state at the Normandy American Cemetery above Omaha Beach, with a speech that focused on recounting the events of 1944 and on paying tribute to those who had participated in the invasion. "Mr. Bush said those who faced the hail of German machine gun fire and artillery, some who made it up over the cliffs and some who did not, had served 'the noblest of causes' and would never be forgotten." ${ }^{27}$ He turned toward President Chirac to add "And America would do it again, for our friends." After the speech Chirac warmly clasped Bush's hand. ${ }^{28}$

Bush in his remarks also reminded the Allies present that the "nations that battled across the continent would become trusted partners in the cause of peace, and our great alliance of freedom is strong, and it is still needed today," a not-so-subtle hint to the French about the need for solidarity in the War on Terror. At the same event President Chirac vowed that "France will 'never forget what it owes to America, its friend forever." ${ }^{29}$ Tom Hanks and Steven Spielberg, the star and director of Saving Private Ryan, were among the crowd-a mixing of real veterans with those who represented them in Hollywood.

\section{A New Generation}

In 2009 with the numbers of surviving WWII veterans drastically shrinking, heads of state again returned to Normandy to mark D-Day-the $65^{\text {th }}$ anniversary of the landings. If President Chirac had made history by inviting Chancellor Schröder and President Putin, President Sarkozy made headlines when it was learned that Queen Elizabeth had not been invited to the anniversary celebrations. French and British officials traded charges about where the blame lay and in the end, after intervention by the Obama administration, Prince Charles attended the Normandy commemoration along with Prime Minister Gordon Brown. ${ }^{30}$ Canadian Prime Minister Stephen Harper also took part. The generational shift first evident in 1994 was now complete. With the absence of Queen Elizabeth, all the Allied leaders taking part in the ceremonies had been born after World War II and had no direct personal memories to contribute. A fresh generation had assumed command, but continued to honor the past while celebrating 
the new. President Obama "invoked his deceased grandfather, 'who arrived on this beach six weeks after D-Day and marched across Europe in Patton's Army.' And he introduced his great-uncle, Charles Payne, who fought in Germany and traveled here from Chicago." ${ }^{31}$ More than had his predecessors Obama also paid extensive tribute to America's World War II home front "On farms and in factories millions of men and women worked three shifts a day, month after month, year after year. Trucks and tanks came from plants in Michigan and Indiana, New York and Illinois. Bombers and fighter planes rolled off assembly lines in Ohio and Kansas, where my grandmother did her part as an inspector." ${ }^{32}$ With President Sarkozy beaming on screen behind President Obama throughout the U.S. President's remarks, the 2009 showcased a visibly warmer Franco-American relationship than had been on display five years earlier. In his own remarks, Sarkozy noted: "The great totalitarian systems of the 20th century have been defeated. The threats that loom over the future of humanity today are of a different kind, but they are no less serious." ${ }^{33}$ British Prime Minister Gordon Brown was so dazzled to be in the presence of the new American president that he made the Freudian slip of referring to Omaha Beach as "Obama Beach." ${ }^{34}$

Placing himself in the tradition that had started with President Reagan, Obama acknowledged, "I'm not the first American President to come and mark this anniversary, and I likely will not be the last." ${ }^{35}$ Over the twenty-five years since the invention of the Normandy "summits," these events have become useful indicators of the state of the transatlantic relationship as well as of intra-European alignments. As the number of WWII veterans decreases to the point of elimination and the ties of the participating Allied leaders to the events become ever more attenuated, the meanings of D-Day become more about the present than the past. But looking back at even the early celebrations of the 1950s where the Marshall Plan and NATO were showcased we see that this has always been the case. The D-Day commemorations simultaneously honored the past while marking new beginnings in domestic politics and transatlantic relations.

\section{NOTES}

1. Marianna Torgovnick, The War Complex: World War II in Our Time (Chicago: University of Chicago Press, 2005) 23. Torgovnick also points out (pp. 40-41) that the total U.S. casualty figures for DDay were 3581, 2403 of whom were killed. These numbers are much lower than those for some other WWII battles that have not acquired D-Day's iconic status.

2. "D-Day Anniversary to be holiday for troops," The New York Times, 3 June 1945, 2.

3. "Normandy Marks D-Day Anniversary," The New York Times, 6 June 1949, 1.

4. "Recovery in France is Hailed," The New York Times, 6 June 1950, 2.

5. "Reds Warned by Ridgway to Avoid War," Washington Post, 7 1952, 3.

6. "Eisenhower Day Serene," The New York Times, 6 June 1954, 30.

7. "Eisenhower Cites D-Day Solidarity," New York Times, 6 June 1954, 30.

8. Val Adams, "Eisenhower going to Normandy to film D-Day program," The New York Times, 15July . 1963, 43. 
9. Robert Brent Toplin, "Hollywood's D-Day from the Perspective of the 1960s and 1990s," in: Peter C. Rollins and John E. O'Connor, eds., Why We Fought: America's Wars in Film and History (Lexington: University Press of Kentucky, 2008) 306.

10. "British Ceremonies on Observances of $20^{\text {th }}$ D-Day Anniversary," Washington Post, 4 June 1964, A8.

11. "D-Day Noted," The New York Times, 1 June1969, 34.

12. The G-7, of course, included nations that fought on both sides of WWII: U.S., France, Britain and Canada representing the Allied forces on D-Day and Germany, Italy and Japan the Axis Powers in WWII.

13. Douglas Brinkley, The Boys of Pointe de Hoc: Ronald Reagan, D-Day and the U.S. Army $2^{\text {nd }}$ Ranger Battalion (New York: HarperCollins, 2005) 4-5

14. Nancy Reagan had received much negative criticism during the first year of the Reagan presidency for wearing designer dresses and spending large sums redecorating the White House (including purchasing a new china service) during a recession. The D-Day program as well as her visit to the National Institute for Blind Youth in Paris would serve to polish the First Lady's public image and divert the focus from fashion during the Reagans' time in France.

15. Enid Nemy, "Mrs. Reagan Visits U.S. Cemetery in Normandy on D-Day Anniversary," The New York Times, 7 June 1982, D7.

16. These two approaches towards the Soviet Union reflect an internal administration debate over the address. See Brinkley, 156.

17. URL: http://www.reagan.utexas.edu/archives/speeches/1984/60684a.htm (accessed $3 / 20 / 2010)$

18. Gil Troy, Morning in America: How Ronald Reagan Invented the 1980s (Princeton: Princeton University Press, 2005) 161.

19. URL: http://www.reagan.utexas.edu/archives/speeches/1984/60684b.htm (accessed $3 / 20 / 2010)$

20. John Vinocur, "Mitterrand Stresses Conciliation,: New York Times, 7 June 1984, A12.

21. William Tuohy, “Allies Sail for D-Day plus 50," Los Angeles Times, 6June 1994.

22. Jeffrey Birnbaum, "Reporter's Notebook: Clinton, Facing Comparison with Reagan's D-Day Speech Rises to occasion," The Wall Street Journal, 7 June 1994, A16.

23. Mary Blume, "Normandy's $50^{\text {th }}$ Anniversary Invasion," The New York Times, 22 January 1994.

24. William Schmidt, “The D-Day Tour: Reminiscences," The New York Times, 4 June 1994.

25. Schröder, however, was not present for President Bush's address at the American Cemetery.

26. Richard Bernstein, "Europa--So far, only silence for a remarkable visit," The New York Times, 28 May 2004.

27. Richard W. Stevenson, "In Normandy, Bush Honors Veterans of D-Day," The New York Times, 6 June 2004.

28. Carl M. Cannon, "Obama in Good Company on D-Day," Politics Daily URL: http://www.politicsdaily.com/2009/06/06/obama-in-good-company-on-d-day/(accessed $3 / 20 / 2010)$

29. Richard W. Stevenson, "In Normandy, Bush Honors Veterans of D-Day," New York Times, 6 June 2004.

30. Andrew Pierce, "Prince of Wales to attend $65^{\text {th }}$ D-Day Anniversary," The Daily Telegraph, 2 June 2009.

31. Jeff Zeleny, "Obama Hails D-Day Heroes at Normandy," The New York Times, 6 June 2009.

32. URL: http://www.whitehouse.gov/the-press-office/remarks-president-d-day-65thanniversary-ceremony (accessed 3/21/2010)

33. Jeff Zeleny, "Obama Hails D-Day Heroes at Normandy," The New York Times, 6 June 2009.

34. Ibid. 
35. URL: http://www.whitehouse.gov/the-press-office/remarks-president-d-day-65thanniversary-ceremony (accessed 3/21/2010)

\section{ABSTRACTS}

This essay investigates what D-Day has symbolized for Americans and how and why its meaning has changed over the past six decades. While the commemoration functions differently in U.S. domestic and foreign policies, in both cases it has been used to mark new beginnings. Ronald Reagan launched his "morning again in America" 1984 re-election campaign from the Pointe du Hoc, and the international commemorations on the Normandy beaches since 1990 have been occasions to display the changing face of Europe and the realignment of allies.

INDEX

Keywords: D-Day, War commemorations, World War II

\section{AUTHOR}

\section{KATE DELANEY}

Massachusetts Institute of Technology 